\title{
CHEMICAL COMPOSITION OF FROZEN BIOFORTIFIED PEPPER AND PUMPKIN
}

\author{
Gregoriy Deinychenko \\ Department of Equipment of Food and Hotel Industry named after M. I. Beliaiev, \\ Kharkiv State University of Food Technology and Trade \\ 333 Klochkivska str., Kharkov, Ukraine, 61051 \\ hduht@kharkiv.com \\ Olha Yudicheva \\ Department of Expertise and Customs \\ Higher Educational Establishment of Ukoopspilka \\ "Poltava University of Economics and Trade» \\ 3 Koval str., Poltava, Ukraine, 36014 \\ olga.iudicheva@yandex.ru
}

\begin{abstract}
Practicability of the use of biofortified sweet pepper of Zoloto Skifov variety and pumpkins of Sviten variety for processing by freezing is proved. The test samples were grown using a liquid, organic, environmentally friendly fertilizers "Riverm" (control - vegetables that were grown using standard technology). Vegetables were frozen at $-23{ }^{\circ} \mathrm{C}$ after preconditioning and packaging. Storage of finished products was at $-18{ }^{\circ} \mathrm{C}$ for 6 months. The research found that during the freezing and storage of vegetables gradual loss of sugars is occurred. Biofortified frozen pepper at 6-th month of storage contains $87.9 \%$ of total initial sugar, biofortified frozen pumpkin $-59.5 \%$.

Test samples of peppers and pumpkins after storage are more valuable for the sugar content than the controls. Changes of pectin amount were observeded during the freezing and storage of samples. After 6 months their content increased by an average of $52 \%$ of the original content in the used raw materials. Tissue content immediately after freezing peppers and pumpkins also increased on average by $61 \%$, but after 3 months of storage began to decline and these changes lasted until the end of life. Freezing had an impact on the amount of hemicellulose in frozen vegetables. After 6 months of storage biofortified vegetables contained an average of $58.1 \%$ of hemicellulose in comparison with its original content. During the freezing and storage of test and control samples of peppers and pumpkins, there is a general pattern of change in the content of sugars and polysaccharides, but after 6 months of storage the most valuable are biofortified vegetables. This is due to the high nutritional value of fresh biofortified vegetables that were used for processing.

Keywords: biofortification, fertilizer, "Riverm", freezing, sugar, pepper, pumpkin.
\end{abstract}

\section{Introduction}

Freezing vegetables consists of three phases. The first phase is cooling from initial to cryoscopic temperatures, the second phase is freezing process and the third phase is further freezing. Rapid freezing is a process in which there is fairly rapid passage of the zone of maximum ice crystal formation, i. e. the temperature range, which in most products range from $-1{ }^{\circ} \mathrm{C}$ to $-5^{\circ} \mathrm{C}$. It promotes the formation of small (average 11, 25, $30 \mathrm{~mm}$ ), evenly distributed in the intercellular space ice crystals. Histological analysis shows that changes in the structure of rapid frozen vegetables are shown as deformation of cells without disturbing their total integrity. Freezing is finished when the equilibrium temperature reaches $-18^{\circ} \mathrm{C}$.

An obligatory condition for rapid frozen food is storage and transportation at $-18{ }^{\circ} \mathrm{C}$ or lower and minimum temperature fluctuations. Only in this case food, particularly vegetables, can be considered as rapid frozen. During the rapid freezing to low temperatures the biochemical processes and development of micro-organisms are completely stopped, therefore, vegetables can be considered as preserved. Rapid freezing isn't flash freezing. Freezing water from the plant cell begins form the temperature of their freezing. Eventually, when there is a loss of heat, more and more water is frozen, and concentration of soluble substances in the cell sap increases. After reaching a certain point, reducing the temperature is further unnecessary because water from the cells no 
longer freezes. A certain amount of it, even at very low temperatures, remains in the liquid phase. An increase of bound water in some frozen fruits and vegetables may occur due to deep protein denaturation (breaking cyclic groupings, destruction of protein chains) that lead to release of hydrophilic group capable of hydration) [1].

Quality and nutritional value are changed in the frozen vegetables. There is a loss of vitamins, change of sugar content and titrated acidity. Also, the color of frozen fruits and vegetables is changed as a result of enzymatic oxidation of polyphenolic compounds. During freezing changes in taste, smell and texture of products are observed that associated with the activity of enzymes and various chemical reactions [2].

One of the main factors that can significantly influence the quality formation of frozen vegetables is high nutritional value and excellent organoleptic properties of the raw materials. Biofortified vegetables that contain many micronutrients are a promising material for freezing.

\section{Literature review and problem statement}

Biofortification primarily involves the creation of new food plants that due to the changes in the genetic apparatus (by genetic engineering means or through the use of classical breeding techniques) are themselves able to accumulate higher levels of vitamins, minerals and other compounds, however, contain reduced number (or do not contain) of anti-nutrients, toxins and other undesirable substances [3]. These new plants include those that can more effectively absorb minerals, penetrate deeper in the soil by the root system and effectively use solutions of compounds that reduces the need for fertilizers. Implementation of biofortification strategy can also realize by creating plants that show signs of improved soil micronutrient mobilization through active transfer of them in bioavailable form, and by using fertilizers that contain targeted minerals [3].

A number of researches on the possibility of using biofortified vegetables for processing are conducted.

The use of biofortified varieties of pumpkins using modern breeding for the production of functional food is able to increase their biological value and help to overcome micronutrient starvation [4-7]. According to the research of 9 varieties of pumpkins from collection seedling of NAS Vegetables and Melon growing Institute (NAS VMI) it was established: the content of vitamin $C$ are significant differences between varieties from $7,1 \cdot 10^{-3} \%$ to $28,1 \cdot 10^{-3} \%$ and marked the most valuable varieties: Ukrainskiy Bagatoplidnyi $\left(28,1 \cdot 10^{-3} \%\right)$, Slavuta $\left(19,4 \cdot 10^{-3} \%\right)$ and Zhdana $\left(17,9 \cdot 10^{-3} \%\right)$. The content of carotenoids in pumpkin ranges $2,3-15,8 \cdot 10^{-3} \%$, which is $50-300 \%$ satisfies the daily need for these substances (daily requirement is $3-5 \cdot 10^{-3} \%$ ). High yields of carotenoids were marked for the pumpkin varieties such as Zhdana $\left(15,8 \cdot 10^{-3} \%\right)$, Arabatskyi $\left(9,8 \cdot 10^{-3} \%\right)$, Khutorianka $\left(9,6 \cdot 10^{-3} \%\right)$, Slavuta $\left(9.0 \cdot 10^{-3} \%\right)$, Khersonskyi and Marmurovyi $\left(6,6 \cdot 10^{-3} \%\right)[8,9]$.

During the research of tomato varieties and hybrids, which are a product of selection of NAS VMI and Kyiv and Donetsk stations of Institute it was found that the carotenoid content is very variable depending on the variety, from $2,3 \cdot 10^{-3} \%$ (Long-Kyper variety) to $12.6 \cdot 10^{-3} \%$ (Malynove Vikante variety). Tomatoes are a source of carotenoids, so satisfying the daily requirement of these substances. For vitamin $\mathrm{C}$ it was also established significant differences between varieties - from $10,8 \cdot 10^{-3} \%$ to $34,5 \cdot 10^{-3} \%$ and marked the most valuable varieties: Amica $\left(34,5 \cdot 10^{-3} \%\right)$, Atlasnyi $\left(283 \cdot 10^{-3} \%\right.$ ), Boian $\left(23,5 \cdot 10^{-3} \%\right)$, Iryshka $\left(23,1 \cdot 10^{-3} \%\right)$, Kremenchugskiy $\left(27,0 \cdot 10^{-3} \%\right)$, Liubimyi $\left(25 \cdot 10^{-3} \%\right)$, Flora $\left(24,3 \cdot 10^{-3} \%\right)$, Lahoranzh $\left(22,8 \cdot 10^{-3} \%\right)$, Iskorka $\left(22,6 \cdot 10^{-3} \%\right)[8,9]$. Quite a significant amount of $\beta$-carotene was found in tomato of varieties Boian $(7.3 \mathrm{mg} / 100 \mathrm{~g})$, Iskorka $(7.4 \mathrm{mg} / 100 \mathrm{~g})$, which allocated in Eastern Ukraine. Amount of ascorbic acid in experimental tomato varieties ranges from 10.3 to $32.6 \mathrm{mg} / 100 \mathrm{~g}$. These biofortified varieties are important raw materials for processing [10, 11].

Biofortified white varieties of white root plants: celery - Jabluchna and President varieties; parsnip - Petrick; parsley - Kharkovjanka and Tsukrova is a valuable raw material for functional vegetable-cheese pastes $[12,13]$.

Today there is no information as how to change the chemical composition of biofortified raw materials using special fertilizer during freezing. With this in mind we researched and frozen sweet pepper of Zoloto Skifov variety and pumpkin of Sviten variety that were grown using organic, environmentally valuable fertilizer "Riverm." These varieties differed by more nutritional value, 
contained increased number of important micronutrients for humans as vitamins and minerals, and also had good organoleptic properties.

The value of research in this direction is to identify the most appropriate methods for processing biofortified vegetables, which can to preserve the nutritional value of raw materials.

\section{Aim and objectives of research}

The aim of the work is studying the chemical composition of frozen biofortified sweet peppers and pumpkins.

To achieve this aim the following objectives were formulated:

- explore the particularities of the sugar content change in the experimental samples of biofortified vegetables after freezing during storage;

- determine the direction of content change for sugars and polysaccharides in biofortified frozen sweet peppers and pumpkins.

\section{Materials and methods}

Objects of research are biofortified sweet pepper of Zoloto Skifov variety and pumpkin of Sviten variety. The test samples were grown using a liquid, organic, environmentally friendly fertilizers "Riverm". The control samples - fresh vegetables that were grown using standard technology without use of the fertilizer. Sweet pepper of Zoloto Skifov variety before freezing were sorted for quality by removing deformed, damaged fruit pests, then calibrated by the size and purified from the stem; the next phase was rinsing of pepper in special mesh conveyors, packaging in plastic bags and freezing at $-23{ }^{\circ} \mathrm{C}$. Vegetables were stored at $-18{ }^{\circ} \mathrm{C}$. Biofortified pumpkin of Sviten variety were released from inedible parts, cleaned, cut into pieces $3 \times 3 \times 3 \mathrm{~cm}$, blanched by the hot steam, cooled, packed in plastic bags and sent to the freezing at $-23^{\circ} \mathrm{C}$. Vegetables were stored at $-18^{\circ} \mathrm{C}$. To research of the sugar permanganate method was used [14], for pectin - titration method [15], for dry matter - a method of drying to constant weight [16], for tissue - a method of direct gravimetric determination [17], for starch - a cyanide method [18].

\section{Research results of chemical composition}

Research of changes in sugar content during storage was conducted for biofortified frozen vegetables, including sweet pepper of Zoloto Skifov variety and pumpkin of Sviten variety. Determination was carried out after the freezing, after 3 and 6 months of storage. Control samples are vegetables that were grown using standard technology without use of the fertilizer "Riverm" (Fig. 1).

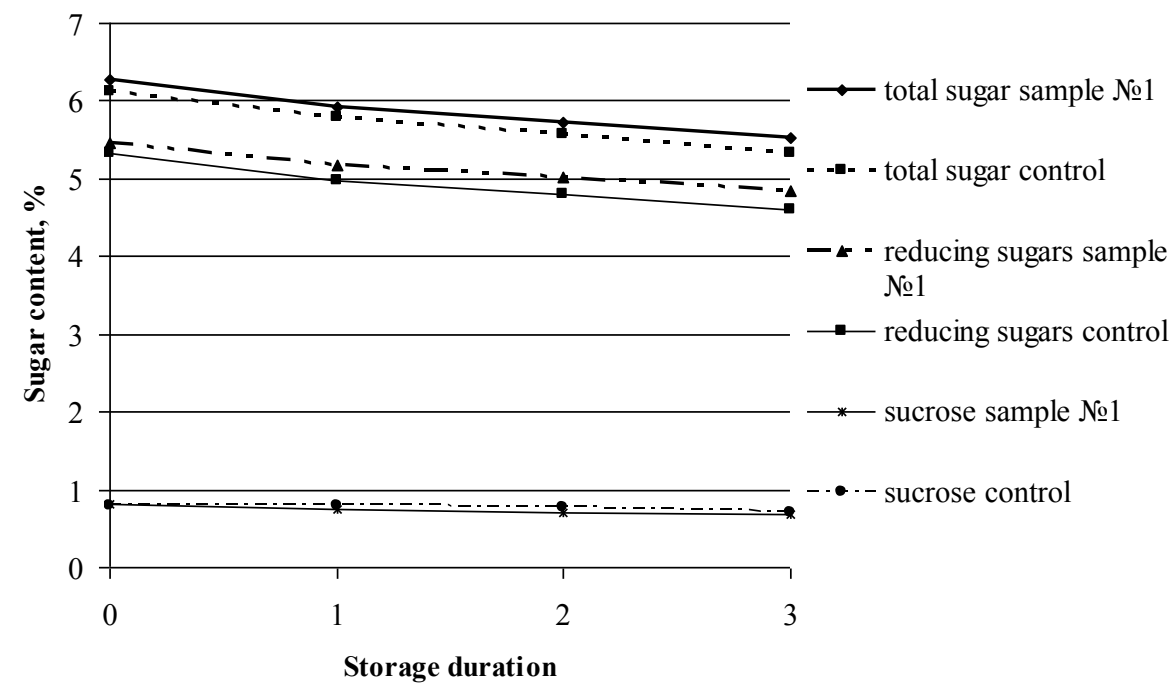

Fig. 1. Changes in sugar content during storage of frozen sweet pepper of Zoloto Skifov variety: 0 - fresh vegetables before freezing; 1 - after freezing; 2 - after 3 months of storage, 3 - after 6 months of storage 
The content of total sugar in biofortified frozen peppers Zoloto Skifov during freezing was changed and after 6 months of storage was $87.9 \%$ of initial content in the raw material (Fig. 1). These changes obviously connected with the activity of invertase in the product. In particular, the amount of reducing sugars decreased during storage at $0.62 \%$. The most transformations of sugars occur during freezing pepper, then during storage, their number gradually decreased (fresh frozen pepper contains less reducing sugars at $0.28 \%$ compared with fresh vegetables, for the first 3 months of storage this amount decreased at $0.16 \%$, and for the next 3 months decreased at $0.18 \%$ ). Changes of total sugar in the control sample of vegetables after 6 months of storage were more pervasive, their number was $86.9 \%$ of the initial total sugar content in fresh vegetables. The difference in changing the total quantity of sugar during freezing can be associated with specific features of raw materials (biofortified peppers were grown using organic fertilizer "Riverm" and control samples - using standard technology). Sugar content in frozen pumpkins is shown in Fig. 2.

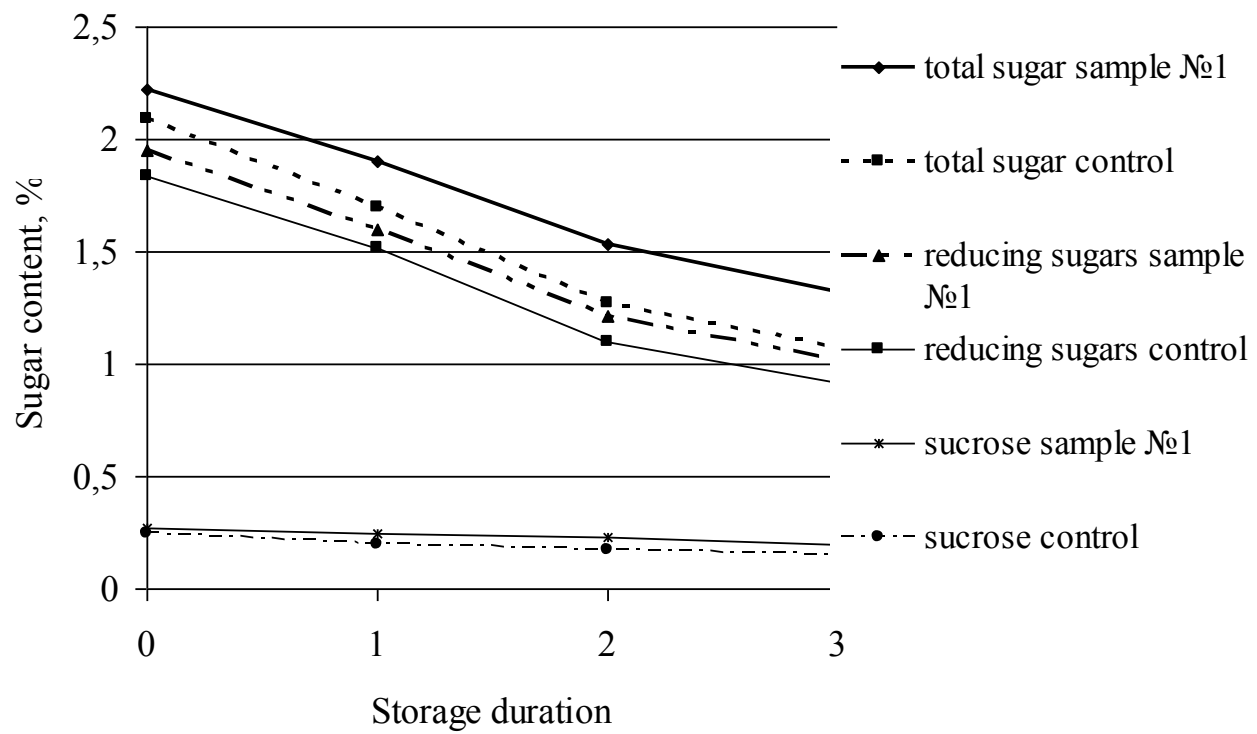

Fig. 2. Changes in sugar content during storage of frozen pumpkin of Sviten variety: 0 - fresh vegetables before freezing; 1 - after freezing; 2 - after 3 months of storage, 3 - after 6 months of storage

Pumpkin of Sviten variety, as a fresh raw material, was differed from sweet pepper of Zoloto Skifov variety by fewer sugars (2.22\% - biofortified vegetables and $2.09 \%$ - control samples). But during the freezing and storage was a significant reduction in the finished product, compared with samples of frozen sweet pepper. After 6 months the sample number 1 (test) contained $59.5 \%$ of total initial sugar. Another difference from frozen pepper was that pumpkins have lost more sugars not in the process of freezing and during storage for 3 months. In particular, after freezing the sample number 1 contains $1.65 \%$ of reducing sugars (by $0.35 \%$ less than in fresh vegetables). After 3 month storage this sample contains $1.21 \%$ of reducing sugars (i. e. $1.39 \%$ less than after freezing) and after 6 months of storage $-1.02 \%$ (the amount of reducing sugars decreased by $0.19 \%$ ). A similar trend is observed in the study of changes of sugar feature and in the control sample, which at the end of storage suffered greater losses of sugars and contained $51.2 \%$ of the initial amount of raw materials. Biofortified frozen vegetables, which are made of biofortified vegetables during freezing suffered smaller losses of sugar compared with the control and were more nutritious.

During freezing biofortified sweet pepper of Zoloto Skifov varietiy and pumpkins of Sviten variety an amount of dry matter and polysaccharides were changed (Table 1). Content of dry matter decreased in all samples and at 6-th month of storage was, \% of original content: $80.2 \%$ (biofortified sweet pepper of Zoloto Skifov variety), $79.8 \%$ (control sample of frozen pepper), 80.9\% (biofortified pumpkins of Sviten variety); 78.5\% (control sample of frozen pumpkins). Reduction of dry matter can be explained by the acceleration of the oxidation process and loss of cell juice 
during defrosting. After 6 months of storage biofortified vegetables had more dry matter than the control samples.

Content of tissue after freezing in all samples increased on average by $61 \%$, but after 3 months of storage its amount in the test samples began to decrease and this direction of change going on in the next months of storage. After 6 months of storage its content in frozen vegetables was more than in the samples of fresh vegetables. Perhaps this is due to the ability of cells damaged by cold forming some polysaccharides [2].

\section{Table 1}

Changes in content of dry matter and polysaccharides in frozen biofortified vegetables

\begin{tabular}{|c|c|c|c|c|c|}
\hline Variants & Dry matter & Cellulose & $\begin{array}{l}\text { Weight part, \% } \\
\text { hemicellulose }\end{array}$ & Pectin & Starch \\
\hline \multicolumn{6}{|c|}{ Pepper of Zoloto Skifov variety (test) } \\
\hline before freezing & 10,26 & 0,79 & 0,21 & 0,18 & 0,17 \\
\hline after freezing & 9,84 & 1,30 & 0,19 & 0,28 & 0,15 \\
\hline $\begin{array}{c}\text { after } 3 \text { months of } \\
\text { storage }\end{array}$ & 9,10 & 1,12 & 0,15 & 0,33 & 0,13 \\
\hline $\begin{array}{c}\text { after } 6 \text { months of } \\
\text { storage }\end{array}$ & 8,23 & 0,86 & 0,12 & 0,37 & 0,11 \\
\hline \multicolumn{6}{|c|}{ Pepper of Zoloto Skifov variety (control) } \\
\hline before freezing & 9,44 & 0,75 & 0,15 & 0,14 & 0,15 \\
\hline after freezing & 9,0 & 1,24 & 0,13 & 0,22 & 0,13 \\
\hline $\begin{array}{c}\text { after } 3 \text { months of } \\
\text { storage }\end{array}$ & 8,26 & 1,03 & 0,11 & 0,26 & 0,11 \\
\hline $\begin{array}{c}\text { after } 6 \text { months of } \\
\text { storage }\end{array}$ & 7,53 & 0,85 & 0,09 & 0,29 & 0,09 \\
\hline \multicolumn{6}{|c|}{ Pumpkin of Sviten variety (test) } \\
\hline before freezing & 8,78 & 0,63 & 0,22 & 0,44 & 4,60 \\
\hline after freezing & 8,35 & 1,06 & 0,20 & 0,71 & 4,57 \\
\hline $\begin{array}{c}\text { after } 3 \text { months of } \\
\text { storage }\end{array}$ & 7,73 & 0,93 & 0,16 & 0,83 & 4,53 \\
\hline $\begin{array}{c}\text { after } 6 \text { months of } \\
\text { storage }\end{array}$ & 7,10 & 0,72 & 0,13 & 0,93 & 4,50 \\
\hline \multicolumn{6}{|c|}{ Pumpkin of Sviten variety (control) } \\
\hline before freezing & 8,36 & 0,63 & 0,19 & 0,35 & 4,37 \\
\hline after freezing & 7,92 & 1,04 & 0,17 & 0,56 & 4,35 \\
\hline $\begin{array}{c}\text { after } 3 \text { months of } \\
\text { storage }\end{array}$ & 7,34 & 0,94 & 0,14 & 0,64 & 4,32 \\
\hline $\begin{array}{c}\text { after } 6 \text { months of } \\
\text { storage }\end{array}$ & 6,56 & 0,69 & 0,11 & 0,73 & 4,30 \\
\hline
\end{tabular}

Hemicellulose content in all samples decreased during freezing and averaged, \% to raw material: $90.7 \%$ (biofortified vegetables) and $88.1 \%$ (control). After 3 months of storage frozen biofortified vegetables contained an average of $75.8 \%$ of its initial hemicellulose content and in control samples $-73.5 \%$. After 6 months of storage biofortified vegetables contained an average of $58.1 \%$ of its initial hemicellulose content in fresh samples and in control samples - an average of $59 \%$. However, the content of pectin in frozen vegetables immediately after freezing increased 1.6 times and during storage it was noted increase of this indicator. After 6 months of storage pectin content in frozen vegetables was increased on average by $52 \%$ compared to 
the raw materials. It is possible that the increasing of pectin is associated with the formation of uronic acids. These acids are formed during the oxidation of monosaccharides. Starch content in frozen vegetables was decreased.

\section{Discussion of research results}

The obtained data about the chemical composition of biofortified sweet peppers and pumpkins after freezing and storage of vegetables characterize these vegetables as promising raw materials for processing. Biofortified peppers and pumpkins using organic fertilizer "Riverm" have high nutritional value, hence for their processing needs to find such ways that would have insignificant impact on the chemical composition and provide good quality products for long-term storage. Freezing is the way of processing that can be applied to biofortified pepper of Zoloto Skifov variety and pumpkins of Sviten variety.

This research is a prolongation of studying chemical composition features of biofortified pumpkin and tomato vegetables using fertilizer "Riverm" during their processing by pickling and freezing. There are plans to explore changing the chemical composition of other pumpkin and tomato vegetables during freezing.

\section{Conclusions}

1. After 6 months of storage test samples of peppers are composed of $87.9 \%$ of total initial sugar (control - $86.9 \%$ ), and samples of pumpkins of Sviten variety - $59.5 \%$ (control $-51.2 \%$ ). Biofortified vegetables during freezing and storage lost fewer sugars.

2. Dry matter content decreases in all samples and at 6 -th month of storage is, $\%$ to raw material: sweet pepper of Zoloto Skifov variety - 80.2\% (test) and $79.8 \%$ (control); pumpkin of Sviten variety $-80.9 \%$ (test) and $78.5 \%$ (control). After 6 months of storage pectin content increased on average by $52 \%$ and fiber content immediately after freezing increased on average by $61 \%$, but after 3 months of storage began to decline. At the 6-th month of storage biofortified vegetables contained an average of $58.1 \%$ of its original hemicellulose content in the raw material.

\section{References}

[1] Barskaia, I. E., Ladyzhanskiy, I. A., Fedorenko, V. T. (1989). Effektivnost proizvodstva bystrozamorozhennoy plodoovoshchnoy produktsii. Moscow: Agropromizdat, 141.

[2] Orlova, N. Ya., Belinska S. O. (2005). Zamorozheni plodoovochevi produkty: problemy formuvannia asortymenty ta yakosti. Kyiv: Kyivskyi natsionalnyi torhivelno-ekonomihnyi universitet, 336.

[3] Burlaka, O. M.\& Sorochynskyy B. V. (2010). Roslynni biotekhnolohii: biofortyfikatsiia kharchovykh roslyn. Kuiv: DIA, 88.

[4] Dubinina, A. A., Shcherbakova, T. V., Shaporova, T. N. et. al. (1997). Vliyaniye razlichnykh faktorov na izmenenie soderzhania karotinoidov v tykve. Aktualni naukovo-metodychni problemy v pidhotovtsi spetsialistiv vyshchoi kvalifikatsii dlia torhivli i kharchuvannia. Kharkiv: KHDATOKH, 1, 48-50.

[5] Dubinina, A. A., Chuyko, L. O., Shaporova, T. N., Ovchynnikova I. F. (1999). Pro kharchovu tsinnist rozroblenoi pasty z morkvy. Novi tekhnolohii ta udoskonalennia protsesiv kharchovykh vyrobnytstv. Kharkiv: KHDATOKH, 232-234.

[6] Dubinina, A. A., Maliuk, L. P., Shaporova, T. N., Penkina, N. M. (2000). Pasta iz tykvy. Pitanie i obshchestvo, 9, 28.

[7] Shaporova, T. N. (2002). Formuvannia spozhyvnykh vlastyvostey past z harbuza ta morkvy. Kharkiv, 154.

[8] Dubinina, A. A., Letuta, T. M., Popova T. M. (2009). Doslidzhennia khimichnoho skladu botanichnykh sortiv harbuza, raynovanykh u Skhidniy Ukraini. Progresyvni tekhnika ta tekhnolohii kharchovykh vyrobnytstv restorannoho hospodarstva i torhivli. Kharkiv: KHDATOKH, 1, 500-509.

[9] Dubinina, A. A. (2014). Naukove obgruntuvannia formuvannia spozhyvnykh vlastyvostei fortyfikovanykh past iz fruktiv ta ovochiv. Kharkiv, 430. 
[10] Dubinina, A. A., Olkhovska, V. S., Yancheva, M. O. (2013). Botanichni osoblyvosti perspektyvnykh sortiv tomativ dlia vyrobnytstva kontsentrovanykh produktiv. Kharkiv: KHDATOKH, 129.

[11] Olkhovska, V. S. (2009). Vdoskonalennia yakosti kontsentrovanykh tomatoproduktiv b protsesi ikh vyrobnytstva. Kharkiv, 170.

[12] Lenert, S. O. (2011). Formuvannia yakosti ovochevo-syrkovykh past pidvyshchenoi biolohichnoi tsinnosti. Kyiv, 20.

[13] Dubinina, S. O., Maliuk, L. P., Popova, T. M. (2007). Doslidzhennia khimichnoho skladu bilykh koreneplodiv. Progresyvni tekhnika ta tekhnolohii kharchovykh vyrobnytstv restorannoho hospodarstva $\mathrm{i}$ torhivli. Kharkiv : KHDATOKH, 208-215.

[14] DSTU 4954:2008 (2009). Produkty pererobky fruktiv ta ovochiv. Metody vyznachennia tsukriv: Kyiv : Derzhspozhyvstandart Ukrainy, 17.

[15] GOST 29059-91(1992). Produkty pererabotki plodov i ovoshchey. Titrometricheskiy metod opredeleniia pektinobykh veshchestv. Moscow: Izdatelstvo standartov, 8.

[16] GOST 28561-90 (1990). Produkty pererabotki plodov i ovoshchey. Metody opredeleniia sukhikh veshchestv I vlahi. Moscow: Izdatelstvo standartov, 14.

[17] GOST 13496.2-91 (1993). Korma, kombikorma, kombikormovoe syrye. Metod opredeleniia syroy kletchatki. Moscow: Izdatelstvo standartov, 6.

[18] GOST 101845-98 (1998). Zerno i produkty ego pererabotki. Metod opredeleniia krakhmala. Moscow: Izdatelstvo standartov, 4. 